al-Kimiya, Vol. 6, No. 1 (36-45) Juni 2019/Syawwal 1440 H

\title{
PEMANFAATAN LIMBAH BIJI ALPUKAT (Persea americana) SEBAGAI BAHAN BAKU BIODIESEL
}

\author{
Nila T BerghuIs ${ }^{1 *}$, PRILlizyA D’URA TAMAKO ${ }^{2}$, DAN ASEP SUPRIADIN ${ }^{3}$ \\ ${ }^{1}$ Program Studi Kimia, Fakultas Sains dan Komputer, Universitas Pertamina, \\ Jl. Teuku Nyak Arif, Jakarta Selatan 12220 \\ 2,3Jurusan Kimia, Fakultas Sains dan Teknologi, UIN Sunan Gunung Djati Bandung, \\ Jl. A. H. Nasution No. 105 Cibiru Kota Bandung \\ *alamat email korespondensi: nila.tanyela@ universitaspertamina.ac.id
}

\begin{tabular}{l} 
Informasi Artikel \\
\hline Riwayat Naskah : \\
Diterima pada 27 \\
Mei 2019 \\
Diterima setelah \\
direvisi pada 3 Juli \\
2019 \\
Diterbitkan pada 5 \\
Juli 2019
\end{tabular}

Kata kunci: biji alpukat; esterifikasi; transesterifikasi; spektrofotometer FTIR; gas chromatography (GC); spesifikasi biodiesel

Keywords: avocado seeds; esterification; transesterification; spectrophotometer FTIR; gas chromatography (GC); specification biodiesel.

\begin{abstract}
Abstrak/Abstract
Biji alpukat merupakan limbah pangan yang mengandung minyak nabati. Salah satu pemanfaatan minyak nabati adalah biodiesel. Biodiesel dapat digunakan sebagai bahan bakar alternatif yang ramah lingkungan dikarenakan dapat menurunkan emisi jika dibandingkan dengan minyak diesel. Penelitian ini bertujuan untuk memanfaatkan biji alpukat sebagai bahan baku sintesis biodiesel serta karakterisasinya. Sintesis biodiesel dilakukan melalui reaksi esterifikasi minyak biji alpukat menggunakan pelarut metanol dengan perbandingan massa 1:20 disertai dengan penambahan katalis asam dan melalui reaksi transesterifikasi menggunakan pelarut metanol dengan perbandingan massa 1:6 dan disertai katalis basa, dengan konsentrasi katalis yang digunakan sebesar 2,5\% dari bobot minyak. Karakterisasi dilakukan dengan analisis spektrofotometer FTIR yang menunjukkan adanya gugus fungsi ester yang merupakan karakteristik dari biodiesel hasil sintesis dengan melihat adanya ikatan $\mathrm{C}-\mathrm{O}$ pada pada bilangan gelombang $1244,09 \mathrm{~cm}^{-1}$ dan ikatan $\mathrm{C}=\mathrm{O}$ pada bilangan gelombang $1737,86 \mathrm{~cm}^{-1}$. Selain itu dilakukan juga analisis Gas Chromatography-Mass Spectroscopy (GC-MS) yang menunjukkan kandungan minyak terbanyak yang berhasil terekstrak dari biji alpukat, yaitu senyawa metil ester oleat dengan waktu retensi 20,618 menit. Pada tahap akhir dilakukan pengujian spesifikasi terhadap biodiesel yang dihasilkan berdasarkan Standar Nasional Indonesia (SNI) 04-7182-2006 yang telah ditetapkan, yang menunjukkan angka asam sebesar $0,4 \mathrm{mg} \mathrm{NaOH} / \mathrm{g}$, massa jenis sebesar $679,335 \mathrm{~kg} / \mathrm{m}^{3}$ dan viskositas kinematik sebesar $4,980 \mathrm{~mm}^{2} / \mathrm{s}$ pada $40^{\circ} \mathrm{C}$, dan warna nyala api biru kemerahan dan tidak berasap yang lebih baik dibandingkan dengan solar.
\end{abstract}

Avocado seed is a food waste containing vegetable oil. One of the utilization of vegetable oil is biodiesel. Biodiesel is one of the most environmentally friendly alternative fuels and can reduce emissions when compared to diesel oil. This research aims to used avocado seed oil as a raw material for making biodiesel, and characteristization. The synthesis of avocado seed oil biodiesel was performed by esterification reaction with a mass ratio of 1:20 using a methanol solvent and a acid catalyst and a transesterification reaction of a mass ratio of 1:6 using a methanol solvent and a base catalyst. The catalyst concentration used is $2.5 \%$ of the weight of the oil. The characterization was performed by FTIR spectrophotometer analysis the characterization of biodiesel synthesis which showed presence of $\mathrm{C}-\mathrm{O}$ (ester) functional group at wave number of $1244.09 \mathrm{~cm}^{-1}$, and $C=O$ (ester) at wave number $1737.86 \mathrm{~cm}^{-1}$, besides that Gas Chromatography-Mass Spectroscopy (GC-MS) analysis showing the oil content which is presence of methyl compound esters of oleate at retention time of 20.618 minute, and the last experiment is testing of specification on biodiesel based on Indonesian National Standard (SNI) 04-7182-2006 which has been determined that the acid number of $0.4 \mathrm{mg} \mathrm{NaOH} / \mathrm{g}$, the density of $40^{\circ} \mathrm{C}$ at $679.335 \mathrm{~kg} / \mathrm{m}^{3}$, kinematic viscosity at $40^{\circ} \mathrm{C}$ at 4.980 $\mathrm{mm}^{2} / \mathrm{s}$, and the flame color of biodiesel is a better reddish and smoky blue color compared to diesel.

\section{PENDAHULUAN}

Kebutuhan manusia akan energi fosil meningkat seiring dengan meningkatnya pendapatan per kapita bangsa Indonesia ditambah pula dengan jumlah penduduk yang semakin meningkat. Hampir $80 \%$ kebutuhan energi dunia saat ini menggunakan bahan bakar fosil. Berdasarkan data statistic dari World Energy, pada akhir tahun 2011 cadangan minyak di dalam perut bumi kita ini hanya tersisa sekitar 4 miliar barel dimana produksi minyak mentah dalam negeri sebesar 942 ribu barel per hari, sehingga dapat diperkirakan dalam jangka waktu kurang dari 12 
tahun kandungan minyak di dalam perut bumi akan habis [1]. Indonesia sendiri, untuk memenuhi kebutuhan energi dalam masa krisis mengandalkan impor sebanyak US\$ 150 juta bahan bakar minyak (BBM) dari negara asing. Menyikapi hal ini, maka diperlukan adanya peningkatan kebutuhan energi dengan melakukan pasokan energi dalam jangka panjang yang berkesinambungan, serta terintegrasi dan ramah lingkungan [2]. Dengan mengetahui sumber energi fosil yang mulai menipis, maka Indonesia harus mencari alternatif lain sebagai sumber energi. Salah satu alternatif pendekatan yang bisa dilakukan adalah dengan memanfaatkan minyak nabati yang melimpah di Indonesia. [3].

Biodiesel adalah bahan bakar alternatif yang ramah lingkungan. Kelebihannya adalah mengurangi emisi gas buang yang meliputi emisi hidrokarbon (HC), karbon monoksida (CO), sulfur oxide (SO), dan partikel-partikel lainnya $[4,5]$, memiliki angka setana $(\mathrm{CN})$ yang cukup tinggi dan pelumasan yang sangat baik dengan titik nyala yang relatif tinggi pada $154^{\circ} \mathrm{C}$, dan biodegradable. [6, 7]. Biodiesel dapat disintesis dari minyak nabati yang berasal dari sumber daya alam yang dapat diperbaharui dan Indonesia kaya akan sumber daya alam nabati [8]. Beberapa penelitian telah dilakukan dalam pencarian bahan baku yang memiliki potensi untuk membuat biodiesel, diantaranya adalah biji jarak pagar, biji alpukat, kedelai, kacang tanah, bunga matahari dan beberapa jenis tumbuhan lainnya [9].

Kandungan minyak dalam biji alpukat sebesar 2638 L/ha ebih banyak dari kandungan minyak pada biji lainnya. Berdasarkan data, kandungan minyak dalam biji jarak pagar sebesar $1892 \mathrm{~L} / \mathrm{ha}$, dalam kedelai sebesar $446 \mathrm{~L} / \mathrm{ha}$, dalam biji bunga matahari sebesar $952 \mathrm{~L} / \mathrm{ha}$, dan dalam kacang tanah sebesar 1059 L/ha [7]. Dan sebagai pertimbangan bahwa buah alpukat banyak terdapat di masyarakat, harganya murah dan bijinya belum dimanfaatkan secara maksimal, maka perlu dilakukan penelitian tentang biji alpukat tersebut [10].

Di dalam minyak biji alpukat terdapat Fatty Acid Methyl Ester (FAME) yang dapat ditransformasi menjadi biodiesel melalui reaksi transesterifikasi maupun esterifikasi. Terhadap minyak hasil sintesis (biodiesel) akan dilakukan karakterisasi dengan menggunakan Spektrofotometer Fourier Transform Infrared (FTIR) untuk melihat perubahan ikatan yang terbentuk sebagai bukti sintesis biodiesel berhasil dilakukan dan karakteristik kandungan metil ester pada biodiesel dengan menggunakan analisis Gas Chromatography-Mass Spectroscopy (GC-MS). Untuk mengetahui spesifikasi dari biodiesel yang disintesis sesuai dengan standar SNI 04-7182-2006, dilakukan analisis yang meliputi penentuan kadar asam lemak bebas (\%FFA), angka asam, massa jenis, viskositas, dan warna nyala.

\section{EKSPERIMEN}

\section{Material}

Bahan dasar sintesis biodiesel ini adalah biji alpukat dari daerah Kasomalang Kota Subang. Adapun bahan-bahan kimia yang digunakan diantaranya adalah pelarut teknis yaitu n-heksana, etanol 96\%, natrium hidroksida (soda api), indikator phenolpthalein, sedangkan bahan yang berasal dari Merck diantaranya yaitu $\mathrm{KOH} 98 \%$ p.a, $\mathrm{Na}_{2} \mathrm{CO}_{3}$ p.a, $\mathrm{Na}_{2} \mathrm{SO}_{4}$ anhidrat p.a, methanol p.a, $\mathrm{HCl}$ p.a, asam oksalat p.a, dan akuades.

\section{Instrumentasi}

Instrumen yang digunakan dalam karakterisasi biodiesel adalah Fourier Transform Infrared (FTIR) merek Shimadzu di Laboratorium Kimia Institut Teknologi Bandung (ITB), sedangkan analisis Gas Chromatography-Mass Spectroscopy (GC-MS) merek Agilent Technologies dilakukan di Laboratorium Kimia Universitas Islam Negeri (UIN) Sunan Gunung Djati Bandung.

\section{Prosedur}

Pemanfaatan minyak biji alpukat (Persea americana) sebagai bahan baku pembuatan biodiesel secara umum dilakukan melalui empat tahap, yaitu ekstraksi minyak biji alpukat, analisis kadar asam lemak bebas minyak, proses esterifikasi dan transesterifikasi, dan karakterisasi biodiesel.

\section{Ekstraksi Minyak Biji Alpukat}

Biji alpukat dilakukan ekstraksi dengan metode soxhlet dengan pelarut n-heksana. Hasil ekstraksi kemudian dipekatkan dengan cara diuapkan dengan menggunakan evaporator vacuum.

\section{Analisis Kadar Asam Lemak Bebas Minyak}

Analisis awal terhadap minyak hasil ekstraksi adalah dengan menentukan kadar asam lemak bebas melalui titrasi. Sebanyak 1 gram sampel minyak biji alpukat ke dalam labu erlenmeyer, lalu ditambahkan $10 \mathrm{~mL}$ etanol 96\%, kemudian ditambahkan 3 tetes indikator phenolphtalein dan dititrasi dengan $\mathrm{NaOH}$ 0,1 M hingga berwarna merah muda tetap selama 15 detik. Titrasi dilakukan duplo, kemudian dihitung \% kandungan asam lemak bebasnya, dengan perhitungan : 


$$
\% \mathrm{FFA}=\frac{\mathrm{V}_{\mathrm{NaOH}} \times \mathrm{M}_{\mathrm{NaOH}} \times \text { Berat molekul asam lemak }}{\text { Berat sampel } \times 1000} \times 100 \%
$$

\section{Proses Esterifikasi dan Transesterifikasi}

Esterifikasi dilakukan dengan metode refluks. Perbandingan mol minyak biji alpukat dengan metanol sebesar 1:20 dan katalis asam (larutan $\mathrm{HCl}$ ) sebanyak 5\% dari berat minyak. Sebanyak 700 gram minyak yang sudah murni dipanaskan dalam labu reaksi selama 15 menit. Suhu reaksi dikontrol pada suhu $50-60^{\circ} \mathrm{C}$. Reaksi dihentikan setelah tercapai waktu reaksi yaitu 60 menit. Setelah reaksi dihentikan, campuran dicuci dengan air hangat $\left(60^{\circ} \mathrm{C}\right)$ dan penambahan larutan $\mathrm{Na}_{2} \mathrm{CO}_{3} 0,01 \%$ sampai $\mathrm{pH}$ campuran netral. Untuk menghilangkan kandungan air, campuran dipanaskan $\pm 120^{\circ} \mathrm{C}$ selama 10 menit. Setelah itu, dilakukan kembali analisis asam lemak bebas dan dihitung kembali kandungan asam lemak bebasnya.

Setelah dilakukan esterifikasi, maka tahapan selanjutnya adalah transesterifikasi dengan perbandingan mol minyak biji alpukat dengan metanol sebesar 1:6 dan katalis basa (larutan $\mathrm{KOH}$ ) sebanyak 2,5\% dari berat minyak. $\mathrm{KOH}$ dilarutkan dengan metanol, direfluks selama 15 menit pada suhu $60^{\circ} \mathrm{C}$, sehingga terbentuk larutan kalium metoksida. Sebanyak 500 gram minyak yang sudah ditimbang sesuai perbandingan mol ditambahkan ke dalam larutan tersebut dan direfluks selama 1 jam pada suhu $50-60^{\circ} \mathrm{C}$. Reaksi dihentikan berdasarkan uji KLT pada saat produk sudah terbentuk.

\section{Proses Pemisahan dan Penyaringan}

Produk hasil transesterifikasi berupa crude/campuran dengan residu berupa gliserol. Pemisahan dilakukan dengan menggunakan corong pisah. Terbentuk dua lapisan berbeda fasa ketika didiamkan selama 12 jam. Fasa atas adalah produk biodiesel, sedangkan fasa bawah adalah gliserol. Lapisan biodiesel yang didapat masih mengandung metanol sehingga perlu dilakukan pencucian. Pencucian dilakukan dengan menambahkan air hangat $\left(50^{\circ} \mathrm{C}\right)$ yang diaduk selama 15 menit dan didiamkan sampai diperoleh lapisan biodiesel dengan pengotor. $\mathrm{Na}_{2} \mathrm{SO}_{4}$ anhidrat ditambahkan untuk mengikat air dan memisahkan dengan baik biodiesel dengan metanol. fasa atas diambil dan dilanjutkan dengan dekantasi untuk memastikan pemisahan metanol-air- $\mathrm{Na}_{2} \mathrm{SO}_{4}$ anhidrat hingga didapatkan biodiesel berwarna kuning jernih.

\section{Karakterisasi Biodiesel}

Analisis spektrofotometer FTIR dan GC-MS
Karakterisasi produk biodiesel dilakukan dengan analisis spektrofotometer FTIR dengan pelat $\mathrm{KBr}$ untuk mengetahui gugus fungsi yang terbentuk di dalamnya, kemudian dianalisis dengan GC-MS untuk mendapatkan kandungan asam lemak dalam biodiesel, serta dilakukan pengujian spesifikasi biodiesel.

\section{Pengujian spesifikasi biodiesel}

Angka asam

Penentuan angka asam dilakukan dengan titrasi. 1 gram sampel minyak biji alpukat ditempatkan ke dalam labu erlenmeyer $250 \mathrm{~mL}$, kemudian ditambahkan $10 \mathrm{~mL}$ etanol $96 \%$ dan 3 tetes indikator phenolphtalein, kemudian dititrasi dengan $\mathrm{NaOH}$ 0,1 $\mathrm{M}$ hingga berwarna merah muda tetap selama 15 detik. Titrasi dilakukan duplo dan dihitung angka asamnya dengan rumus di bawah ini:

$$
\text { Angka asam }=\frac{\mathrm{V}_{\mathrm{NaOH}} \times \mathrm{M}_{\mathrm{NaOH}} \times \mathrm{BM} \mathrm{NaOH}}{\text { gram sampel }}
$$

Catatan: $\mathrm{BM}=$ berat molekul produk sintesis biodiesel

Nilai angka asam sebelum reaksi dibandingkan dengan nilai sesudah reaksi.

Massa jenis

Perhitungan massa jenis biodiesel dilakukan dengan menggunakan piknometer. Volume piknometer didapatkan dengan menghitung selisih dari berat piknometer kosong dengan berat piknometer yang telah diisi penuh dengan akuades (pada suhu $40^{\circ} \mathrm{C}$ ). Hal yang sama dilakukan untuk menghitung massa jenis biodiesel. Perhitungan menggunakan rumus di bawah ini:

$$
\begin{gathered}
\mathrm{V}_{\text {piknometer }}=\frac{\mathrm{W}_{(\text {piknometer+akuades })}-\mathrm{W}_{\text {piknometer kosong }}}{\rho_{\text {air }}\left(\mathrm{t}=40^{\circ} \mathrm{C}\right)} \\
\rho_{\text {biodiesel }}=\frac{\mathrm{W}_{\text {(piknometer+biodiesel) }}-\mathrm{W}_{\text {piknometer kosong }}}{\mathrm{V}_{\text {piknometer }}}
\end{gathered}
$$

\section{Viskositas}

Pengukuran viskositas digunakan viskositas air sebagai standar. Sebanyak $25 \mathrm{~mL}$ air dipipet ke dalam viskometer Ostwald lalu diatur sehingga 
viskometer dapat berdiri secara vertikal dalam termostat, kemudian dilakukan pengaturan suhu pada suhu $40^{\circ} \mathrm{C}$ dan ditunggu selama 5 menit. Selanjutnya dilakukan pemasangan filler, kemudian air dihisap hingga melewati dua tanda batas. Filler dilepaskan dan kemudian dimulai perhitungan waktu dengan stopwatch ketika air melewati batas pertama. Stopwatch dihentikan ketika air sudah melewati batas kedua dan waktu yang diperlukan air untuk melewati batas kedua tersebut dicatat, dengan perhitungan:

$$
\begin{gathered}
\eta=\eta_{0}=\frac{\mathrm{t} . \rho}{t_{0} \cdot \rho_{0}} \\
\frac{\eta_{\text {larutan }}}{\eta_{\text {air }}}=\frac{\rho_{\text {larutan }}}{\rho_{\text {air }}} \times \frac{\mathrm{t}_{\text {larutan }}}{\mathrm{t}_{\text {air }}} \\
\eta_{\text {larutan }}=\frac{\eta_{\text {air }} \times \mathrm{t}_{\text {larutan }} \times \rho_{\text {larutan }}}{\rho_{\text {air }} \times \mathrm{t}_{\text {air }}}
\end{gathered}
$$

Warna nyala

Untuk melihat perbedaan warna api dan sifat fisik lainnya antara biodiesel dan solar dilakukan uji warna nyala, yaitu dengan memasukkan biodiesel dan solar ke dalam vial yang telah dilengkapi dengan sumbu, kemudian vial yang telah diisi dengan biodiesel dan solar dibakar dan perbedaan diantara keduanya diamati.

\section{HASIL DAN PEMBAHASAN}

Sampel yang digunakan pada penelitian ini adalah biji alpukat yang didapat dari penjual jus di daerah Kasomalang Kabupaten Subang. Untuk menghilangkan kandungan air dari biji alpukat, maka biji yang telah dicuci dan dikupas bersih dikeringkan di dalam oven pada suhu $105-110^{\circ} \mathrm{C}$. Berat sampel kering yang dihasilkan sebanyak 3,6 $\mathrm{kg}$ atau sebanyak $28,8 \%(b / b)$ terhadap sampel biji alpikat basah.

Tabel 1. Data hasil pengeringan sampel

\begin{tabular}{cccc}
\hline $\begin{array}{c}\text { Jenis } \\
\text { Sampel }\end{array}$ & $\begin{array}{c}\text { Berat Sampel } \\
\text { Basah }(\mathrm{kg})\end{array}$ & $\begin{array}{c}\text { Berat Sampel } \\
\text { Kering }(\mathrm{kg})\end{array}$ & $\begin{array}{c}\text { Kadar } \\
\text { Air }(\%)\end{array}$ \\
\hline $\begin{array}{c}\text { Biji } \\
\text { Alpukat }\end{array}$ & 12,5 & 3,6 & 71,26 \\
\hline
\end{tabular}

Data hasil pengeringan sampel biji alpukat dapat dilihat pada Tabel 1. Tahapan selanjutnya adalah penghalusan biji yang sudah kering dengan cara digiling menggunakan blender untuk memaksimalkan proses ekstraksi.

\section{Ekstraksi Minyak Biji Alpukat}

Sampel sebanyak 3,6 kg dimasukkan dalam alat Soxhlet. Pelarut yang digunakan adalah nheksana. Pemanasan pelarut organik dilakukan sampai pelarut tidak berwarna lagi yang menandakan bahwa pelarut sudah tidak membawa komponen yang ingin diisolasi. Suhu yang digunakan adalah $60-70^{\circ} \mathrm{C}$ yang merupakan suhu optimum pelarut $n$-heksana untuk ekstrak minyak. Hasil soxhletasi menghasilkan minyak yang terlarut di dalam pelarut heksana. Pemisahan dilakukan dengan metode evaporasi pada suhu $40^{\circ} \mathrm{C}$ sehingga diperoleh berat minyak sebanyak 700 gram dengan volume $782 \mathrm{~mL}(19,44 \%)$. Data lengkap hasil soxhletasi dapat dilihat pada Tabel 2.

Tabel 2. Data hasil soxhletasi

\begin{tabular}{cccc}
\hline $\begin{array}{c}\text { Massa biji } \\
\text { alpukat }(\mathrm{g})\end{array}$ & $\begin{array}{c}\text { Massa } \\
\text { minyak biji } \\
\text { alpukat }(\mathrm{g})\end{array}$ & $\begin{array}{c}\text { Volume } \\
\text { minyak biji } \\
\text { alpukat (mL) }\end{array}$ & $\begin{array}{c}\text { Kadar } \\
\text { Minyak } \\
(\%)\end{array}$ \\
\hline 3600 & 700 & 782 & 19,44 \\
\hline
\end{tabular}

\section{Kadar Asam Lemak Bebas Minyak}

Analisis Asam lemak bebas dilakukan untuk mengetahui kualitas dari minyak yang berhasil diisolasi. Hal ini dikarenakan ketika kadar asam lemak bebas sangat tinggi, maka kualitas dari minyak tersebut sangat rendah. Analisis ini berkaitan dengan nilai bilangan asam. Semakin besar angka asam suatu minyak atau lemak, maka kandungan asam lemak bebas dalam sampel semakin tinggi. Keberadaan asam lemak bebas dapat diakibatkan karena adanya proses hidrolisis yang terjadi pada saat minyak diekstraksi.

Sampel yang berupa minyak biji alpukat ditambahkan dengan etanol 96\%, kemudian direaksikan dengan basa alkali. Hasil yang didapatkan adalah nilai kandungan asam lemak bebas biji alpukat yaitu sebesar 15,16\%, yang menunjukkan hasil FFA tinggi $(>5 \%)$ dan karenanya maka diperlukan proses esterifikasi untuk menurunkan bilangan FFA agar terhindar dari pembentukan emulsi (sabun) yang dapat menghambat proses pemisahan gliserol dengan metil ester (biodiesel) pada saat proses pencucian.

\section{Proses Esterifikasi}

Sintesis biodiesel dari minyak yang mengandung asam lemak bebas tinggi harus diawali dengan reaksi esterifikasi yang dilanjutkan dengan reaksi transesterifikasi. Reaksi esterifikasi bertujuan untuk mengonversi asam lemak bebas menjadi ester sampai jumlah asam lemak di bawah standar. Katalis yang digunakan adalah $\mathrm{HCl} 37 \%$ dan pelarut metanol yang merupakan pelarut protik, sehingga 
dapat menyeimbangkan anion yang terbentuk dari katalis setelah melepaskan proton. Dalam reaksi esterifikasi dapat digunakan katalis asam maupun basa, namun katalis asam memiliki keunggulan yaitu tetap efektif selama reaksi berlangsung dalam minyak yang masih memiliki kandungan asam lemak bebas yang tinggi. Perbandingan mol minyak dengan metanol yang digunakan sebesar 1:20 dan jumlah katalis yang digunakan sebanyak $5 \%$ dari berat minyak. Jumlah ini sudah cukup untuk menurunkan FFA minyak biji alpukat yang diesterifikasi.

Mekanisme reaksi esterifikasi berkatalis asam dapat terlihat pada Gambar 1, yaitu mekanisme awal melibatkan proses pertukaran gugus hidroksil dari suatu karboksilat dengan gugus alkil dari alkohol dan menghasilkan air. Proses ini adalah proses penentu laju dikarenakan sangat lambat. Secara kinetika dengan menggunakan perbandingan mol dimana jumlah metanol yang cukup banyak sangat membantu pada tahapan ini karena akan mendorong reaksi ke arah pembentukan produk. Mekanisme reaksi esterifikasi terdiri dari beberapa tahap yaitu transfer proton dari katalis asam ke atom oksigen karbonil untuk meningkatkan elektrofilitas dari atom karbon karbonil, sehingga oksigen dari alkohol yang bersifat nukleofilik dapat menyerang karbon karbonil dan terbentuk ion oksonium. Selanjutnya pelepasan proton terjadi dari gugus hidroksil alkohol menghasilkan kompleks teraktivasi dan protonasi terhadap salah satu gugus hidroksil yang diikuti oleh pelepasan molekul air menghasilkan senyawa ester.

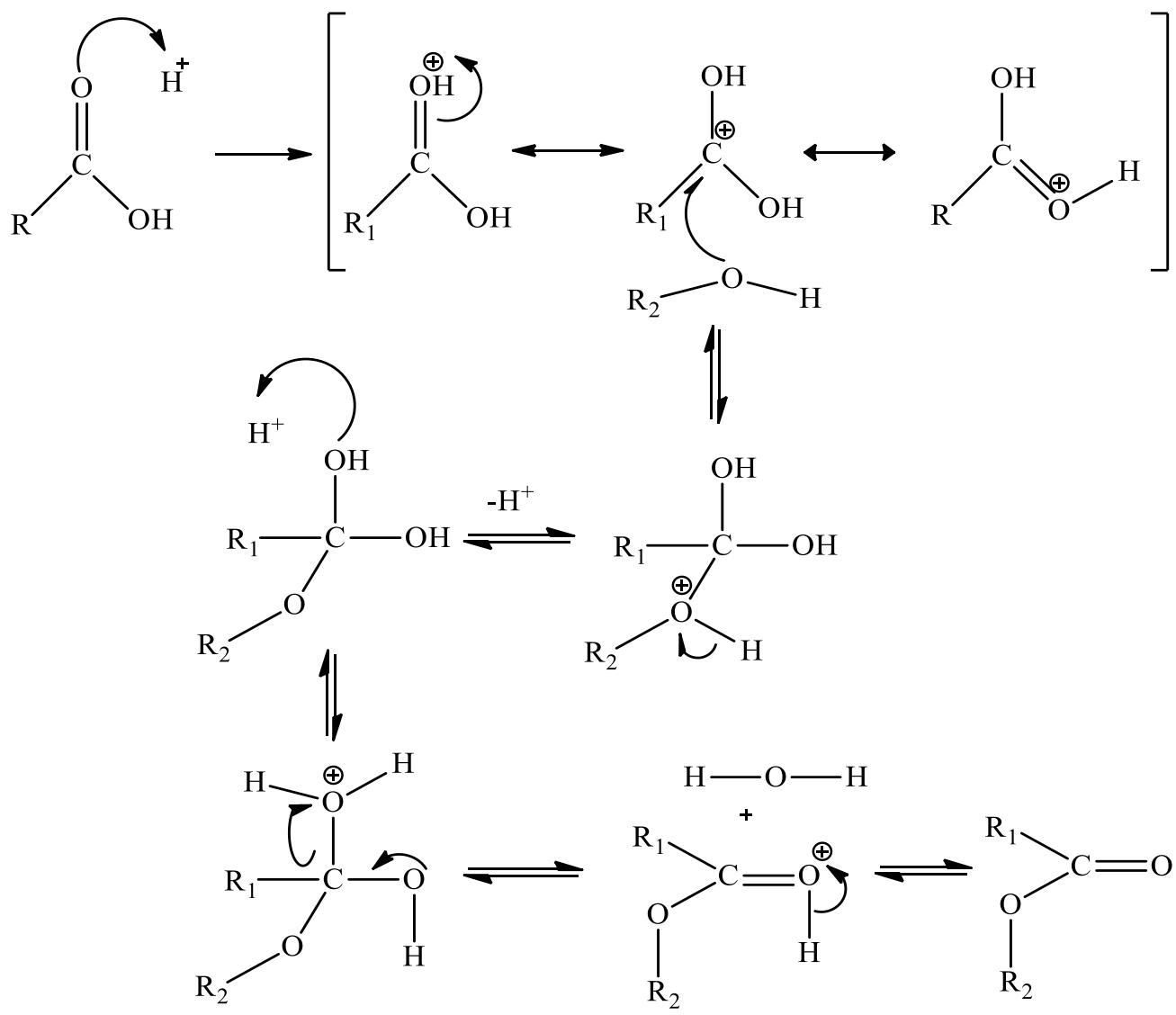

Gambar 1. Mekanisme reaksi esterifikasi asam lemak

Dalam proses esterifikasi, reaksi dilakukan selama \pm 1 jam dengan suhu $50-60^{\circ} \mathrm{C}$ dalam labu didih yang dilengkapi dengan pengadukan dan refluks. Suhu ini diambil karena merupakan titik didih dari metanol. Penambahan $\mathrm{Na}_{2} \mathrm{CO}_{3}$ bertujuan agar menetralkan sisa katalis asam dalam campuran dan dicuci dengan air dengan suhu $60^{\circ} \mathrm{C}$ untuk melarutkan zat pengotor yang bersifat polar. Pemanasan yang cukup tinggi $\left(120^{\circ} \mathrm{C}\right)$ dilakukan untuk menguapkan air sebagai residu dari proses esterifikasi. Kandungan air yang tinggi dapat mengganggu proses transesterifikasi yaitu terjadinya reaksi hidrolisis atau reaksi kebalikan dari reaksi transesterifikasi. Setelah proses esterifikasi, FFA dalam minyak dihitung kembali dan didapatkan nilai sebesar $0,54 \%$. Hasil tersebut menunjukkan bahwa kandungan asam lemak bebas dalam minyak biji alpukat turun dari minyak awal sebesar $15,16 \%$. 


\section{Proses Transesterifikasi}

Transesterifikasi merupakan reaksi alkoholisis dari ester karena reaksi tersebut disertai dengan pertukaran bagian alkohol dari suatu ester. Reaksi transesterifikasi dapat mengonversi minyak biji alpukat yang telah diesterifikasi menjadi metil ester asam lemaknya. Reaksi yang terjadi yaitu trigliserida bereaksi dengan metanol, sehingga dihasilkan gliserol dan terjadi pemutusan asam lemak menjadi esternya. Reaksi transesterifikasi menggunakan katalis basa $\mathrm{KOH}$. Mekanisme yang terjadi, ion metoksida yang berasal dari reaksi metanol dengan katalis basa, yang merupakan nukleofilik kuat, dapat dengan mudah menggantikan gugus karbonil pada asam lemak. Untuk lebih jelas mengenai mekanisme reaksi transesterifikasi dapat dilihat pada Gambar 2.

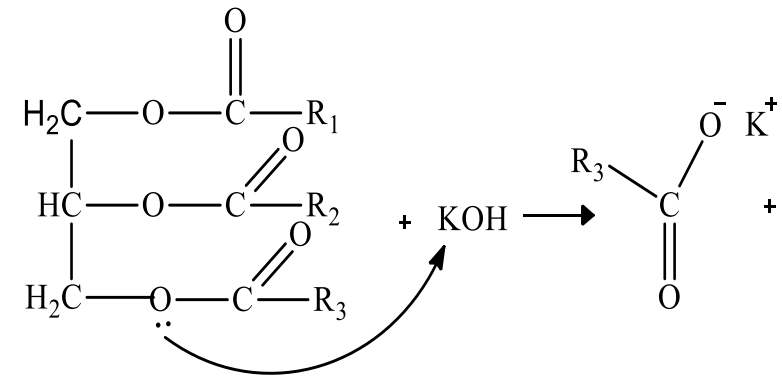

Trigliserida<smiles>[R]C(=O)OCC(CO)OC([R])=O</smiles>

digliserida

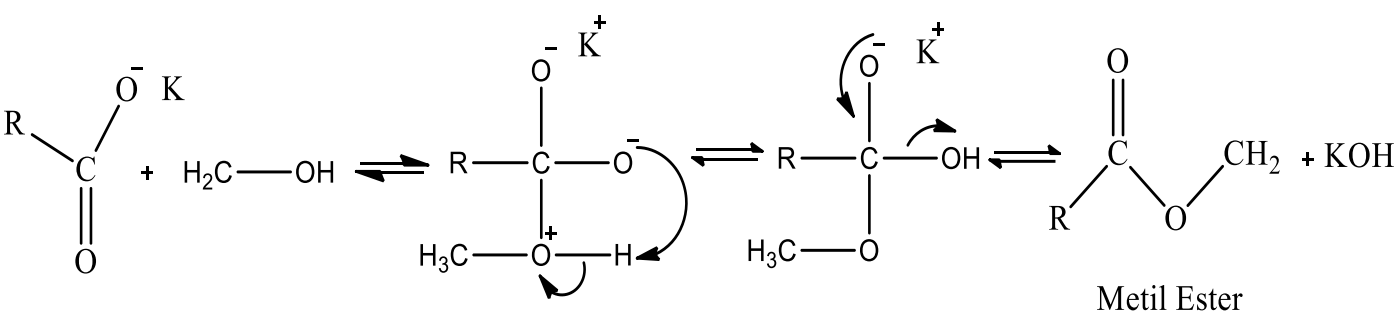

Gambar 2. Mekanisme reaksi transesterifikasi

Proses ini dilakukan dengan menggunakan alkohol rantai pendek yang mudah melarutkan lemak yaitu metanol dengan katalis basa kuat yaitu $\mathrm{KOH}$ dengan perbandingan mol antara minyak dengan metanol yang digunakan yaitu 1:6, sedangkan katalis basa sebanyak 2,5\% dari berat minyak. Katalis basa kuat bertujuan untuk mempercepat reaksi yang umumnya lebih cepat dibandingkan dengan menggunakan katalis asam dikarenakan reaksi berlangsung searah, sedangkan pemakaian katalis basa berlangsung sempurna. Penggunaan katalis basa harus seminimal mungkin untuk menghindari proses saponifikasi. Rasio molar minyak dengan alkohol yang digunakan adalah 1:6 dikarenakan rasio molar tersebut merupakan konversi minyak dengan alkohol maksimal yaitu antara 98-99\%. Reaksi ini berlangsung secara setimbang di mana salah satu reaktan (metanol) harus dibuat berlebih agar diperoleh hasil yang optimal. Reaksi dilakukan selama \pm 1 jam dengan suhu $50-60^{\circ} \mathrm{C}$ dalam labu didih yang dilengkapi dengan pengadukan dan refluks. Secara stoikiometri, dibutuhkan $1 \mathrm{~mol}$ trigliserida dan 3 mol alkohol.
Reaksi ini dipengaruhi oleh karakteristik dari minyak yang digunakan seperti kandungan air, kandungan asam lemak bebas, dan kandungan zat terlarut maupun tak terlarut yang dapat mempengaruhi reaksi. Faktor lain diantaranya adalah suhu, waktu, kecepatan pengadukan, jenis dan konsentrasi katalis, dan jumlah rasio molar metanol terhadap minyak. Proses ini akan berlangsung lebih cepat apabila suhu dinaikkan mendekati titik didih metanol yaitu $50-60^{\circ} \mathrm{C}$.

Hasil reaksi berupa 2 fasa, yaitu lapisan atas berwarna kuning jernih dan lapisan bawah berwarna coklat pekat. Lapisan atas yang berbentuk cair adalah metil ester sedangkan lapisan bawah adalah gliserol. Metil ester yang terbentuk kemudian dipisahkan dari gliserol kemudian dicuci dengan air $\left(50^{\circ} \mathrm{C}\right)$ untuk membersihkan metil ester dari metanol, katalis dan gliserol yang masih terdapat pada metil ester. Setelah proses pencucian, terbentuk kembali dua fasa karena adanya perbedaan massa jenis antara metil ester dengan air, yang mana metil ester berada pada bagian atas dan air berada pada bagian bawah. Untuk memisahkan campuran, dilakukan penyaringan dengan penambahan $\mathrm{Na}_{2} \mathrm{SO}_{4}$ anhidrat pada kertas saring 
yang bertujuan untuk menyerap air yang masih terdapat dalam metil ester. Metil ester yang terbentuk berwarna kuning jernih.

\section{Analisis Biodiesel}

Analisis Spektrofotometer FTIR
Analisis spektrofotometer FTIR digunakan untuk mengetahui perubahan gugus fungsi yang terdapat dalam sampel metil ester (biodiesel) dengan membandingkan dengan sampel minyak awal. Perbandingan spektrum hasil analisis spektrofotometer FTIR untuk sampel minyak biji alpukat dan minyak biodiesel dapat dilihat pada Gambar 3.

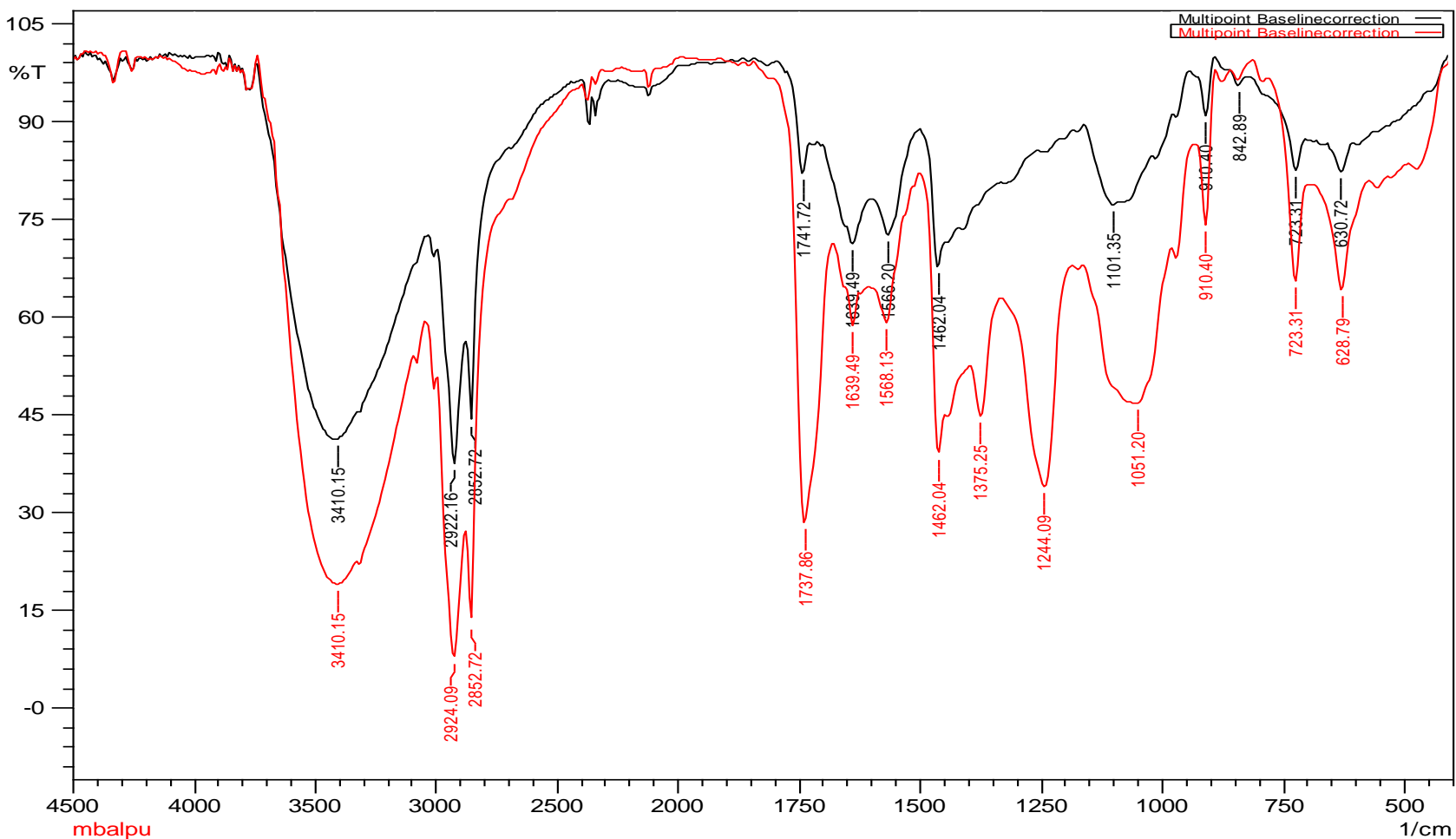

Gambar 3. Overlay spektrum Fourier Transform-Infrared (FTIR) pada sampel minyak biji alpukat (hitam) dan minyak biodiesel (merah)

Tabel 3. Daerah serapan bilangan gelombang pada produk biodiesel

\begin{tabular}{ccccccc}
\hline No & $\begin{array}{c}\text { Daerah } \\
\text { Serapan } \\
\left(\mathrm{cm}^{-1}\right)\end{array}$ & Ikatan & $\begin{array}{c}\text { Nama } \\
\text { Gugus } \\
\text { Fungsi }\end{array}$ & $\begin{array}{c}\text { Bilangan Gelombang Terukur }\left(\mathrm{cm}^{-1}\right) \\
\text { Minyak Biji } \\
\text { Alpukat }\end{array}$ & Minyak Biodiesel & Keterangan \\
\hline 1 & $1050-1260$ & C-O & Eter & 1101,35 & 1051,2 & Ulur \\
2 & $1110-1300$ & C-O & Ester & - & 1244,09 & Ulur \\
3 & $1740-1760$ & C=O & Ester & 1741,72 & 1737,86 & Ulur, Tidak simetris \\
4 & $1445-1475$ & C-H & Metil & 1462,04 & 1462,04 & Simetris \\
5 & $2820-2975$ & C-H & Metil & 2852,72 & $2852,722924,09$ & Ulur, Tidak simetris \\
6 & $1600-1700$ & C=C & Alkena & 1639,49 & 1639,49 & Ulur \\
7 & $3000-3700$ & O-H & Alkohol & 3410,15 & 3410,15 & Ulur \\
8 & $675-1000$ & - CH=CH- & Alkena & 723,31 & 723,31 & Ulur \\
\hline
\end{tabular}

Berdasarkan data spektrum pada Gambar 3 dan Tabel 3, sampel minyak biji alpukat terdapat puncak pada bilangan gelombang $1101,35 \mathrm{~cm}^{-1}$ yang menunjukkan adanya vibrasi ikatan $\mathrm{C}-\mathrm{O}$ dari gugus eter, puncak pada bilangan gelombang $1741,72 \mathrm{~cm}^{-1}$ yang menunjukkan adanya vibrasi ikatan $\mathrm{C}=\mathrm{O}$ dari gugus ester, puncak pada bilangan gelombang 1462,04 $\mathrm{cm}^{-1}$ yang menunjukkan adanya vibrasi ikatan $\mathrm{C}-\mathrm{H}$ dari suatu hidrokarbon alifatik, puncak pada bilangan gelombang 2852,72 $\mathrm{cm}^{-1}$ yang menunjukkan adanya vibrasi ikatan $\mathrm{C}-\mathrm{H}$ dari rantai asam lemak, puncak pada bilangan 
gelombang $1639,49 \mathrm{~cm}^{-1}$ yang menunjukkan adanya vibrasi ikatan $\mathrm{C}=\mathrm{C}$ dari asam lemak bebas, puncak pada bilangan gelombang $3410,15 \mathrm{~cm}^{-1}$ yang menunjukkan adanya vibrasi ikatan $\mathrm{O}-\mathrm{H}$, puncak pada bilangan gelombang $723,31 \mathrm{~cm}^{-1}$ yang menunjukkan adanya vibrasi ikatan $-\mathrm{CH}=\mathrm{CH}$ - dari rantai asam lemak tak jenuh. Sedangkan untuk sampel minyak biodiesel terjadi pergeseran bilangan gelombang, yaitu di antaranya muncul puncak pada bilangan gelombang $1051,20 \mathrm{~cm}^{-1}$ yang menunjukkan adanya vibrasi ikatan $\mathrm{C}-\mathrm{O}$ dari eter, puncak pada bilangan gelombang $1244,09 \mathrm{~cm}^{-}$ ${ }^{1}$ yang menunjukkan adanya vibrasi ikatan $\mathrm{C}-\mathrm{O}$ dari ester, puncak pada bilangan gelombang 1737,86 $\mathrm{cm}^{-1}$ yang menunjukkan adanya vibrasi ikatan $\mathrm{C}=\mathrm{O}$ dari ester, puncak pada bilangan gelombang $1462,04 \mathrm{~cm}^{-1}$ yang menunjukkan adanya vibrasi ikatan $\mathrm{C}-\mathrm{H}$, puncak pada bilangan gelombang 2852,72 dan $2924,09 \mathrm{~cm}^{-1}$ yang menunjukkan adanya vibrasi ikatan $\quad \mathrm{C}-\mathrm{H}$ dari rantai asam lemak, puncak pada bilangan gelombang 1639,49 $\mathrm{cm}^{-1}$ yang menunjukkan adanya vibrasi ikatan $\mathrm{C}=\mathrm{C}$ dari asam lemak bebas, puncak pada bilangan gelombang $3410,15 \mathrm{~cm}^{-1}$ yang menunjukkan adanya vibrasi ikatan $\mathrm{O}-\mathrm{H}$, dan puncak pada bilangan gelombang 723,31 $\mathrm{cm}^{-1}$ yang menunjukkan adanya vibrasi ikatan $-\mathrm{CH}=\mathrm{CH}$ - dari rantai asam lemak tak jenuh. Adanya tumpang tindih beberapa vibrasi ikatan menunjukkan bahwa tidak $100 \%$ asam lemak telah tertransesterifikasi.

\section{Analisis GC-MS}

Analisis pengujian GC-MS dilakukan untuk mengetahui jenis asam lemak penyusun metil ester dari biji alpukat hasil reaksi esterifikasi dan transesterifikasi. Metode GC-MS digunakan untuk pemisahan secara kuantitatif maupun kualitatif dan analisis asam lemak dengan terlebih dahulu dibuat turunan asam lemaknya. Hasil analisis spektrofotometer GC-MS untuk sampel minyak biodiesel dapat dilihat pada Gambar 4.

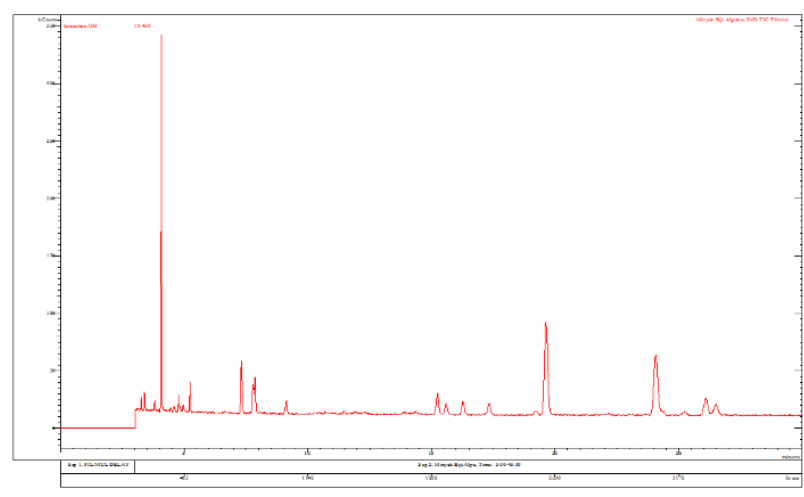

Gambar 4. Kromatogram GC dari produk biodiesel
Berdasarkan hasil analisis Gas Chromatography-Mass Spectroscopy (GC-MS) pada produk biodiesel, hasil sintesis terdapat berbagai metil ester yang teridentifikasi. Analisis GC-MS menggunakan senyawa standar untuk mempermudah identifikasi dengan melihat kemiripan pola fragmentasi dan waktu retensi. Spektra massa dari senyawa-senyawa metil ester beserta senyawa standarnya dapat dilihat pada Tabel 4.

Tabel 4. Waktu retensi dari produk biodiesel

\begin{tabular}{|c|c|c|c|c|}
\hline No & $\begin{array}{c}\text { Nama asam } \\
\text { lemak }\end{array}$ & Formula & $\begin{array}{l}\text { Waktu } \\
\text { Retensi } \\
\text { standar } \\
\text { (sec) }\end{array}$ & $\begin{array}{l}\text { Waktu } \\
\text { Retensi yang } \\
\text { diukur (sec) }\end{array}$ \\
\hline 1 & $\begin{array}{l}\text { Metil ester } \\
\text { heksanoat }\end{array}$ & C6:0 & 6,031 & 6,028 \\
\hline 2 & $\begin{array}{l}\text { Metil ester } \\
\text { miristat }\end{array}$ & C14:0 & 15,878 & 15,084 \\
\hline 3 & $\begin{array}{l}\text { Metil ester } \\
\text { miristoleat }\end{array}$ & C14:1 & 16,275 & 16,275 \\
\hline 4 & $\begin{array}{l}\text { Metil ester } \\
\text { palmitat }\end{array}$ & C16:0 & 17,996 & 17,999 \\
\hline 5 & $\begin{array}{l}\text { Metil ester } \\
\text { palmitoleat }\end{array}$ & C16:1 & 18,311 & 18,311 \\
\hline 6 & $\begin{array}{l}\text { Metil ester } \\
\text { stearat }\end{array}$ & C18:0 & 20,332 & 20,332 \\
\hline 7 & $\begin{array}{l}\text { Metil ester oleat } \\
\text { (9) }\end{array}$ & C18:1 & 20,617 & 20,618 \\
\hline 8 & $\begin{array}{l}\text { Metil ester oleat } \\
\text { (11) }\end{array}$ & C18:1 & 20,697 & 20,692 \\
\hline 9 & $\begin{array}{l}\text { Metil ester } \\
\text { linoleat }\end{array}$ & C18:2 & 21,205 & 21,202 \\
\hline 10 & $\begin{array}{l}\text { Metil ester } \\
\text { linolenat }\end{array}$ & $\mathrm{C} 18: 3$ & 22,052 & 22,052 \\
\hline 11 & $\begin{array}{l}\text { Metil ester } \\
\text { aracidat }\end{array}$ & C20:0 & 22,857 & 22,857 \\
\hline 12 & $\begin{array}{l}\text { Metil ester } \\
\text { eikosonat }\end{array}$ & C20:1 & 23,166 & 23,164 \\
\hline 13 & $\begin{array}{l}\text { Metil ester } \\
\text { eikosadienat }\end{array}$ & C20:2 & 23,808 & 23,802 \\
\hline 14 & $\begin{array}{l}\text { Metil ester } \\
\text { aracidonat }\end{array}$ & C20:4 & 24,551 & 24,551 \\
\hline 15 & $\begin{array}{l}\text { Metil ester } \\
\text { eikosatrienoat } \\
\text { Metil Ester }\end{array}$ & C20:3 & 24,730 & 24,728 \\
\hline 16 & $\begin{array}{l}\text { Behenat dan } \\
\text { metil ester } \\
\text { eikosapenta- } \\
\text { enoat }\end{array}$ & $\begin{array}{l}\text { C22:0 } \\
\text { C20:5 }\end{array}$ & 25,582 & 25,586 \\
\hline 17 & $\begin{array}{l}\text { Metil ester } \\
\text { erukat }\end{array}$ & C22:1 & 26,031 & 26,030 \\
\hline 18 & $\begin{array}{l}\text { Metil ester } \\
\text { lignosenat }\end{array}$ & $\mathrm{C} 24: 0$ & 29,574 & 29,573 \\
\hline 19 & $\begin{array}{l}\text { Metil ester } \\
\text { nervonat }\end{array}$ & $\mathrm{C} 24: 1$ & 30,203 & 30,205 \\
\hline 20 & $\begin{array}{l}\text { Metil ester } \\
\text { dokosaheksaeno } \\
\text { at }\end{array}$ & C22:6 & 30,365 & 30,363 \\
\hline \multicolumn{5}{|c|}{$\begin{array}{l}\text { *Sumber: James D McCurry.Ph.D, "GC/MS Analysis of Trace Fatty } \\
\text { Acid Methyl Esters (FAME) in Jet Fuel Using Energy Institude Method } \\
\text { IP585," Agilent Technologies, Inc. } 2850 \text { Centerville Road } \\
\text { Wilmington, DE } 19808 \text { USA, USA,. }\end{array}$} \\
\hline
\end{tabular}


Kandungan metil ester pada biodiesel biji alpukat diantaranya metil ester heksanoat, metil ester miristat, metil ester miristoleat, metil ester palmitat, metil ester palmitoleat, metil ester stearat, metil ester oleat, metil ester linoleat, metil ester linolenat, metil ester arachidat, metil ester eikosonat, metil ester eikosadienat, metil ester arachidonat, metil ester eikosatrienoat, metil ester behenat, metil ester eikosapentaenoat, metil ester erukat, metil ester lignosenat, metil ester nervonat, dan metil ester dekosaheksaenoat.

\section{Pengujian Spesifikasi Biodiesel}

Pengujian spesifikasi biodiesel minyak biji alpukat dilakukan untuk mengetahui kesesuaiannya dengan Standar Nasional Indonesia (SNI) 04-71822006 yang telah ditetapkan. Spesifikasi biodiesel yang telah dilakukan adalah sebagai berikut:

\section{Angka asam}

Angka asam adalah jumlah miligram yang diperlukan untuk menetralkan asam lemak bebas yang terdapat dalam 1 gram minyak atau lemak. Angka asam dari biodiesel biji alpukat yang dihasilkan sebesar $0,4 \mathrm{mg} \mathrm{NaOH} / \mathrm{g}$. Nilai ini sudah memenuhi SNI yaitu maksimum $0,5 \mathrm{mg} \mathrm{NaOH} / \mathrm{g}$.

Rendahnya asam lemak yang dihasilkan menunjukkan kandungan asam lemak bebas pada bahan baku minyak biji alpukat telah menurun. Angka asam yang tinggi akan menyebabkan minyak biodiesel bersifat korosif dan dapat menimbulkan jelaga atau kerak di injektor mesin diesel.

\section{Massa jenis}

Massa jenis adalah nilai yang menunjukkan perbandingan berat per satuan volume. Massa jenis terkait dengan viskositas, jika biodiesel mempunyai massa jenis yang melebihi ketentuan, akan terjadi reaksi tidak sempurna pada konversi minyak nabati. Nilai ini merupakan indikator panjangnya rantai karbon, peningkatan jumlah ikatan rangkap pada asam lemak, rendahnya zat-zat pengotor, seperti sabun dan gliserol hasil reaksi penyabunan, asam-asam lemak yang tidak terkonversi menjadi metil ester, air, katalis sisa, ataupun sisa metanol yang terdapat dalam biodiesel. Massa jenis biodiesel minyak biji alpukat yang dihasilkan sebesar $679,335 \mathrm{~kg} / \mathrm{m}^{3}$. Nilai ini tidak masuk ke dalam rentang nilai SNI yaitu 850$890 \mathrm{~kg} / \mathrm{m}^{3}$.

\section{Viskositas}

Viskositas merupakan nilai yang menunjukkan berapa besar ketahanan yang dimiliki fluida ketika dialirkan ke dalam pipa kapiler terhadap gaya gravitasi dan biasanya dinyatakan dalam waktu yang diperlukan untuk mengalir pada jarak tertentu. Analisis viskositas sangat mempengaruhi proses atomisasi bahan bakar, tekanan injeksi, serta ukuran lubang injektor. Viskositas yang lebih tinggi akan membuat bahan bakar teratomisasi menjadi tetesan yang lebih besar dengan momentum tinggi dan memiliki kecenderungan bertumbukan dengan dinding silinder yang relatif lebih dingin. Hal ini menyebabkan pemadaman flame dan peningkatan deposit, penetrasi semprot bahan bakar, dan emisi mesin. Sebaliknya bahan bakar dengan viskositas rendah akan memproduksi spray yang terlalu halus dan tidak dapat masuk lebih jauh ke dalam silinder pembakaran, sehingga terbentuk daerah fuel rich zone yang menyebabkan pembentukan jelaga. Viskositas juga menunjukkan sifat pelumasan atau lubrikasi dari bahan bakar. Viskositas yang relatif tinggi mempunyai sifat pelumasan yang lebih baik.

Viskositas kinematik pada $40^{\circ} \mathrm{C}$ biodiesel minyak biji alpukat yang dihasilkan sebesar $4,980 \mathrm{~mm}^{2} / \mathrm{s}$. Nilai ini sudah memenuhi SNI yaitu maksimum 2,3-6,0 $\mathrm{mm}^{2} / \mathrm{s} \quad(\mathrm{cSt})$. Rendahnya viskositas dikarenakan tingkat efektivitas proses reaksi yang tinggi.

\section{Warna nyala}

Warna nyala api dihasilkan dari proses oksidasi yang terjadi berlangsung cepat pada saat proses pembakaran. Warna yang muncul menunjukkan jumlah energi yang dihasilkan. Warna api biru akan memberikan energi panas yang jauh lebih banyak dibandingkan dengan nyala api yang berwarna merah. Faktor yang mempengaruhi warna nyala api adalah faktor fisika yaitu suhu dan faktor kimia. Api merah umumnya bersuhu di bawah $1000^{\circ} \mathrm{C}$, Sedangkan api biru bersuhu lebih tinggi dari api merah yaitu di bawah $2000^{\circ} \mathrm{C}$. Perbandingan warna nyala antara minyak biodiesel dengan minyak solar dapat dilihat pada

\section{Gambar 5.}

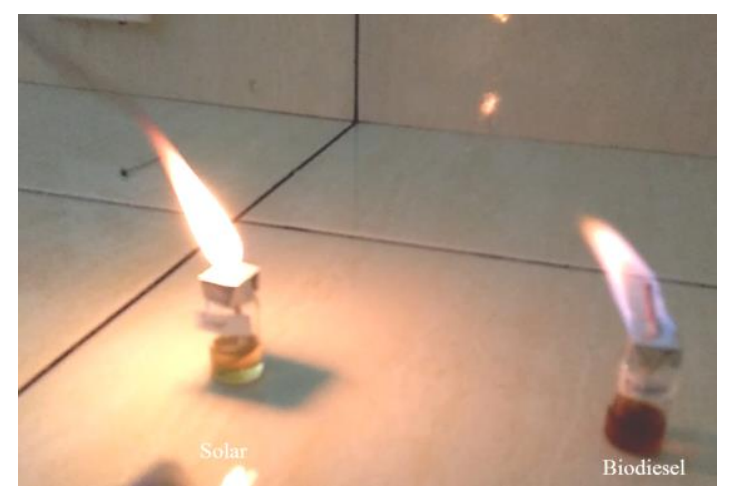

Gambar 5. Warna nyala antara minyak biodiesel dengan minyak solar 
Berdasarkan pengujian warna nyala antara minyak biodiesel dengan minyak solar, dapat dilihat perbandingan di antara keduanya yaitu pada minyak biodiesel warna nyala api berupa warna biru kemerahan sedangkan minyak solar berwarna merah. Nyala api solar yang berwarna merah menunjukkan reaksi oksidasi yang lebih lambat dibandingkan dengan nyala api biodiesel yang berwarna biru, sehingga energi yang dihasilkan juga lebih sedikit. Api terjadi dari reaksi pembakaran senyawa yang mengandung oksigen $\left(\mathrm{O}_{2}\right)$. Jika suatu reaksi pembakaran kekurangan oksigen, maka efisiensi pembakaran berkurang dan menghasilkan suatu senyawa karbon seperti asap atau jelaga seperti pada minyak solar, hal tersebut dapat membuktikan bahwa pembakaran minyak biodiesel lebih baik dan tidak mengeluarkan emisi yang dapat merusak lingkungan sekitar dibandingkan solar.

\section{SIMPULAN}

Dari hasil penelitian ini dapat ditarik kesimpulan bahwa kandungan minyak biji alpukat yang didapatkan yaitu $19,44 \%$. Karakteristik minyak biodiesel dari biji alpukat dapat dilihat berdasarkan terbentuknya senyawa metil ester yang didukung oleh data FTIR sebagai berikut: adanya gugus $\mathrm{C}-\mathrm{O}$ dari ester pada bilangan gelombang $1244,09 \mathrm{~cm}^{-1}$, adanya gugus $\mathrm{C}=\mathrm{O}$ dari ester pada bilangan gelombang $1737,86 \mathrm{~cm}^{-1}$, dan juga dapat diperkuat dengan hasil data $\mathrm{GC}$ yang menyatakan di dalam biodiesel biji alpukat mengandung metil ester oleat pada waktu retensi 20,618 menit. Pengujian spesifikasi sesuai standar SNI yaitu angka asam sebesar $0,38 \mathrm{mg} \mathrm{NaOH} / \mathrm{g}$ minyak, massa jenis pada suhu $40^{\circ} \mathrm{C}$ sebesar 679,335 $\mathrm{kg} / \mathrm{mm}^{2}$, viskositas kinematik pada $40^{\circ} \mathrm{C}$ sebesar $4,980 \mathrm{~mm}^{2} / \mathrm{s}$ (cSt), dan warna nyala biodiesel yang lebih baik dibandingkan dengan solar.

\section{UCAPAN TERIMA KASIH}

Ucapan terimakasih penulis sampaikan kepada pihak-pihak yang telah membantu penulis dalam menyelesaikan penelitian ini.

\section{REFERENSI}

[1] Bristish Petrolium. (2013) Statistical Review Of World Energy. https:// bp.com/statisticalreview

[2] Nurjannah, A. Roesyadi, dan D. H. Prajitno, "Perengkahan katalitik minyak sawit untuk menghasilkan biofuel", Reaktor, vol. 13, no. 1, pp. 37-43, 2010.

[3] R. Handoyo, A. A. Anggraini, dan S. Anwar, "Biodiesel dari minyak biji kapok," Jurnal Enjiniring Pertanian, vol. V, no. 1, pp. 57-64, 2007.

[4] R. M. Joshi dan M. J. Pegg, "Flow properties of biodiesel fuel blends at low temperatures" Fuel, vol. 86, no. 1-2, pp. 143-151, 2007.

[5] US Department of Energy 2004 Biodiesel Handling and use guidelines, DOE/GO102004-1999, revised November 2004.

[6] Smith PC, Ngothai Y, Nguyen QD, and O'neill $\mathrm{BK}$, "Improving the low temperature properties of biodiesel, methods and consequences", Renewable Energy, vol. 35, no. 6, pp. 1145-1151, 2010.

[7] F. Maa, dan M. A. Hanna, "Biodiesel production: a review", Bioresour Technology, vol. 70, no. 1, pp. 1-15, 1999.

[8] M. Ghiaci, B. Aghabarari, and A. Gil, "Production of biodiesel by esterification of natural fatty acids over modified organoclay catalysts" Fuel, vol. 90, no. 11, pp. 3382-3389, 2011.

[9] S. Risnoyatiningsih, "Biodiesel from avocado seeds by transesterification process", Jurnal Teknik Kimia, vol. 5, no. 1, p. 345-351, 2010.

[10] Prasetyowati, R. Pratiwi, dan F. Tris O., "Pengambilan minyak biji alpukat (persea americana mill) dengan metode ekstraksi", Jurnal Teknik Kimia, vol. 17, no. 2, pp. 16-24, 2010. 